\title{
Instrumen Penilaian Kelincahan Tubuh Anak Usia Dini
}

\section{Feny Aries Diana ${ }^{1}$, I Nyoman Jampel2 ${ }^{2}$ Putu Aditya Antara ${ }^{3}$}

1,3 Prodi Pendidikan Guru Pendidikan Anak Usia Dini, Universitas Pendidikan Ganesha, Singaraja, Indonesia

${ }^{2}$ Prodi Teknologi Pendidikan, Universitas Pendidikan Ganesha, Singaraja, Indonesia

\section{ART I C L E I N F O}

\section{Article history:}

Received September 01, 2021

Revised September 03, 2021

Accepted November 20, 2021

Available online December 25, 2021

Kata Kunci:

Kelincahan Tubuh Anak, Instrumen Penilaian

Keywords:

Child Body Agility, Assessment Instrument

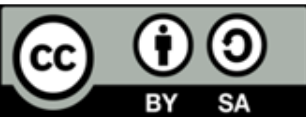

This is an open access article under the CC BY-SA license.

Copyright (c) 2021 by Author. Published by Universitas Pendidikan Ganesha.

\begin{abstract}
A B S T R A K
Kurangnya perhatian terhadap perkembangan motorik kasar anak usia dini, yang disebabkan oleh kurang tepatnya metode dan alat penilaian yang digunakan untuk memfasilitasi siswa dalam pembelajaran dan kurang kreatifnya guru dalam mengemas pembelajaran yang menarik. Penelitian ini bertujuan untuk mengembangkan instrumen penilaian untuk meningkatkan kelincahan tubuh pada anak usia dini. Jenis penelitian yang digunakan merupakan penelitian pengembangan Research and Development yang dilaksanakan menggunakan model RDR. Subjek penelitian yang digunakan terdiri atas dua orang pakar ahli, instrumen penilaian kelincahan tubuh anak yang terdiri dari kisi-kisi dan lembar kuesioner dengan jumlah pernyataan sebanyak 16 butir. Metode pengumpulan data dilakukan melalui uji ahli/pakar kemudian data yang terkumpul dianalisis dengan menggunakan rumus Gregory dan Cronbach Alpha untuk mengukur validitas dan reliabilitas instrumen. Hasil penelitian ini yaitu hasil penilaian yang dilakukan dilakukan oleh kedua pakar ahli terhadap instrumen yang dikembangkan dalam kategori valid. Dapat disimpulkan bahwa instrumen penilaian kelincahan tubuh pada anak yang telah dikembangkan dinyatakan layak dan dapat digunakan dalam proses pembelajaran. Implikasi penelitian ini yaitu instrumen penilaian yang dikembangkan dapat digunakan sebagai alat penilaian yang dapat memfasilitasi guru dalam proses pembelajaran sehingga dapat meningkatkan kemampuan motorik kasar khususnya kemampuan kelincahan tubuh anak.
\end{abstract}

\section{A B S T R A C T}

Lack of attention to gross motor development of early childhood is caused by the lack of precise methods and assessment tools used to facilitate students in learning and the lack of creativity of teachers in enjoyable packaging learning. This study aims to develop an assessment instrument to improve body agility in early childhood. The type of research used is Research and Development development research, which uses the RDR model. The research subjects used consisted of two experts, a child's body agility assessment instrument consisting of a grid, and a questionnaire sheet with 16 statements. The data collection method was carried out through expert/expert tests, and then the collected data were analyzed using the Gregory and Cronbach Alpha formulas to measure the validity and reliability of the instrument. The results of this study are the results of the assessment carried out by the two experts on the instruments developed in the excellent category. It can be concluded that the body agility assessment instrument in children that has been developed is declared feasible and can be used in the learning process. This research implies that the assessment instrument developed can be used as an assessment tool that can facilitate teachers in the learning process to improve gross motor skills, especially the agility ability of the child's body.

\section{PENDAHULUAN}

Anak usia dini adalah anak yang berada pada rentang usia 0-6 tahun. Pada masa ini anak mengalami masa perkembangan yang sangat pesat yang dikenal dengan masa keemasan atau golden age dimana pada masa itu anak harus mendapatkan stimulus dan pendidikan yang tepat untuk setiap tahap perkemangannya (Fadlullah, 2017; Wulandari \& Purwanta, 2020). Pendidikan anak usia dini ialah pendidikan yang paling penting bahkan menjadi landasan yang kokoh bagi terwujudnya generasi yang lebih cerdas, berkarakter, dan terampil. Salah satu tujuan perkembangan anak usia dini merupakan 
pengembangan kepribadian anak serta kemampuan fisik motorik, nilai agama dan moral, kognitif, bahasa, sosial emosional, dan seni (Darihastining, Aini, Maisaroh, Diana, 2021; Ruiyat, Yufiarti \& Kardani, 2019). Umumnya setiap tugas perkembangan harus dialami oleh anak usia dini. Namun tidak semua anak dapat mengalami tugas perkembangan dengan baik, apabila anak melewati satu tahapan perkembangan akan mempengaruhi pertumbuhan dan perkembangan anak itu sendiri (Ruqoyyah \& Meidita, 2021; Ramadhani \& Zulminiati, 2021). Taman kanak-kanak merupakan salah satu pendidikan formal bagi anak usia dini (Marwiyati \& Istiningsih, 2020; Yuliani, Antara \& Magta, 2017). Aspek yang diterapkan pada jenjang pedidikan PAUD adalah aspek perkembangan (Fauziddin, 2015; Suwatra, Magta \& Christiani, 2019). Masamasa pada rentang usia dini merupakan dimana perkembangan anak berlangsung sangat pesat dan merupakan masa yang sangat baik untuk belajar (Melendez \& Tafur, 2021; Antara, 2015a). Dari enam aspek perkembangan yang saling mempengaruhi satu dengan yang lainnya. Salah satunya adalah aspek fisik motorik yang didalamnya terdiri dari kelincahan (Antara, 2019; Widiastuti \& Ridwan, 2018).

Unsur pokok dalam pembelajaran fisik motorik merupakan kelincahan. Kelincahan merupakan gerak tubuh yang cepat dan akurat dengan melibatkan semua anggota tubuh yang mempengaruhi posisi badan (Widiastuti \& Ridwan, 2018; Usher, 2019). Kelincahan pada diri anak usia dini dapat dilihat ketika anak melakukan suatu gerakan yang bisa diukur dengan kelincahannya. Kegiatan fisik seperti berjalan, berlari, melompat membutuhkan kemampuan kelincahan agar otot-otot yang mulai berkembang dapat berfungsi dengan baik (Fitriani, 2018; Antara, 2019; Trisnaningsih, Wiyasa \& Darsana, 2019). Pada anak usia 5 hingga 6 tahun kelincahan sudah dapat dilihat dan perkembangannya merupakan yang paling menonjol perkembangannya (Antara, 2019; Trisnaningsih, Wiyasa \& Darsana, 2019). Kelincahan juga dapat menjadi tolak ukur kemampuan perubahan posisi gerak tubuh yang cepat dan terarah (Widiastuti \& Ridwan, 2018; Uzun \& Akbulut, 2020). Anak yang memiliki kemampuan kelincahan yang baik akan memiliki perkembangan mental yang baik pula (Usher, 2019; Sukoyo, Wiyati \& Utami, 2021). Anak dapat belajar dengan sebaik-baiknya apabila kebutuhan fisiknya dipenuhi dan mereka akan merasa aman dan nyaman secara psikologis. Kemampuan tersebut akan berkembang dengan maksimal apabila mendapatkan stimulus yang tepat dari orangtua maupun guru. Guru merupakan tenaga pendidik dengan tugas utamanya mengajar serta keberhasilannya sangat penting dan berpengaruh terhadap pengembangan sumber daya manusia (Antara, 2019b; Wibowo, 2016).

Permasalahan yang terjadi saat ini yaitu kurang tepatnya instrumen atau alat penilaian yang digunakan untuk menilaia kelincahan tubuh anak (Umami, Rusdi \& Kamid, 2021; Zahro, 2015a). Permasalahan ini juga ditemukan pada salah satu taman kanak-kanak. Berdasarkan hasil observasi yang dilakukan di taman kanak-kanak Candikuning II ditemukan permasalahan yakni alat penilaian yang digunakan untuk penilai perkembangan kelincahan anak berupa hasil karya dan tanya jawab. Saat kegiatan kelincahan tubuh seagian anak tidak mau berpartisipasi dalam kegiatan, sehingga guru harus memancing beberapa anak agar semua anak dapat berpartisipasi dalam kegiatan. Saat proses pembelajaran diharapkan semua anak dapa berpartisipasi sehingga dapat meningkatkan pemahaman anak (Cahyaningrum, Sudaryanti \& Purwanto, 2017; Khadijah, Hardianti \& Maisarah, 2021). Permasalahan lainnya yang ditemukan yaitu kurang menariknya media pembelajaran yang digunakan yang dapat memotivasi anak dalam proses pembelajaran kelincahan tubuh anak, media yang digunakan bersifat monoton kurang menarik minat serta perhatian siswa dalam proses pembelajaran. Media yang biasanya digunakan dalam kegiatan perkembangan kelincahan tubuh berupa permainan perosotan sehingga masih banyak anak yang kurang antusias saat proses pembelajaran. Hal ini menyebabkan masih banyak anak yang belum maksimal dalam perkembangan kelincahan tubuhnya.

Berdasarkan permasalahan tersebut, maka solusi yang dapat diberikan untuk melatih kelincahan tubuh anak adalah dengan mengembangkan instrumen atau alat penilaian kelincahan tubuh dengan berbagai macam kegiatan dan media-media dalam instrumen yang akurat dan layak digunakan. Instrumen penilaian merupakan alat yang digunakan untuk memperoleh data sehingga dapat memecahkan suatu masalah dan mencapai suatu tujuan (Salamah, 2018; Zuliani, Florentinus \& Ridlo, 2017). Media-media yang digunakan dalam instrumen dapat meningkatkan semangat dan motivasi siswa dalam proses pembelajaran (Putri, Handayani \& Akbar, 2020; Zeptyani \& Wiarta, 2020). Tujuan instrumen penelitian dilakukan guna mengetahui seberapa dalam kesuksesan guru dalam pembelajaran dan sebagai umpan balik untuk proses pembelajaran yang akan dilakukan selanjutnya tentang apa yang dibutuhkan peserta didik (Zahro, 2015; Aji \& Winarno, 2016). Instrumen penilaian ini disusun berdasarkan teori-teori yang mengkaji tentang kemampuan kelincahan tubuh pada anak usia dini.

Penelitian relevan sebelumnya mengenai metode kelincahan tubuh anak yang dikembangkan dimana tujuan dalam penelitian ini untuk mengetahui pengaruh modifikasi latihan fisik terhadap kelincahan tubuh anak dengan menggunakan instrumen kelincahan tubuh, sampel dalam penelitian ini berjumlah 16 anak dengan hasil yang didapatkan bahwa pengembangan instrumen layak digunakan untuk melatih kemampuan kelincahan tubuh anak (Yulianti \& Fithroni, 2019a; Fadila \& Ilmayanti, 2021). Temuan 
penelitian lainnya juga menyatakan bahwa model kelincahan bagi siwa taman kanak-kanak yang dihasilkan dalam penelitian ini menyatakan bahwa model kelincahan tubuh yang dikembangkan efektif digunakan dan diterapkan untuk anak usia dini, hasil yang didapatkan dalam penelitian ini melalui dua kali uji coba model kelincahan yang diberikan kepada kelompok besar dengan hasil yang sangat baik (Widiastuti, Ridwan, 2018). Melalui pengembangan instrumen ini pendidik akan lebih mudah menilai kemampuan fisik motorik anak dengan lebih akurat, dengan pemilihan kegiatan-kegiatan yang telah dicantumkan dalam pengembangan instrumen ini agar anak merasa senang dan tidak bosan dengan kegiatan-kegiatan di sekolah. Sehingga secara langsung pendidik dapat menstimulasi otot-otot besar anak, dan anak merasa aktivitas yang mereka jalani merupakan aktivitas baru dan tidak monoton. Tujuan penelitian ini adalah untuk mengembangkan instrumen penilaian yang digunakan untuk melihat perkembangan kelincahan tubuh anak usia dini dengan melakukan kegiatan-kegiatan yang telah disusun didalam instrumen yang dikembangkan sehingga dapat menstimulasi langsung perkembangan kelincahan tubuh anak usia dini.

\section{METODE}

Penelitian ini melibatkan jenis penelitian RND (Research and Development) dengan menerapkan model pengembangan RDR (Research Development Research) dari Brog \& Gall (Nurmasitah, Achmad \& Prasetyaningtyas, 2017; Wanto et al., 2020). Prosedur penelitian disajikan pada Gambar 1. Prosedur pengembangan instrumen penilaian menggunakan model RDR terdiri atas: research (studi pendahuluan) yang dilakukan untuk mendapatkan terkait kebutuhan dan permasalahan yang terjadi di lapangan, development (pengembangan) yang dilakukan dengan menetapkan dan merancang produk berupa instrumen penilaian kelincahan tubuh pada anak usia dini yang akan dihasilkan, research (uji efektivitas produk) yang dilakukan dengan melibatkan pakar ahli untuk menilai kelayakan instrumen penilaian kelincahan tubuh pada anak usia dini.

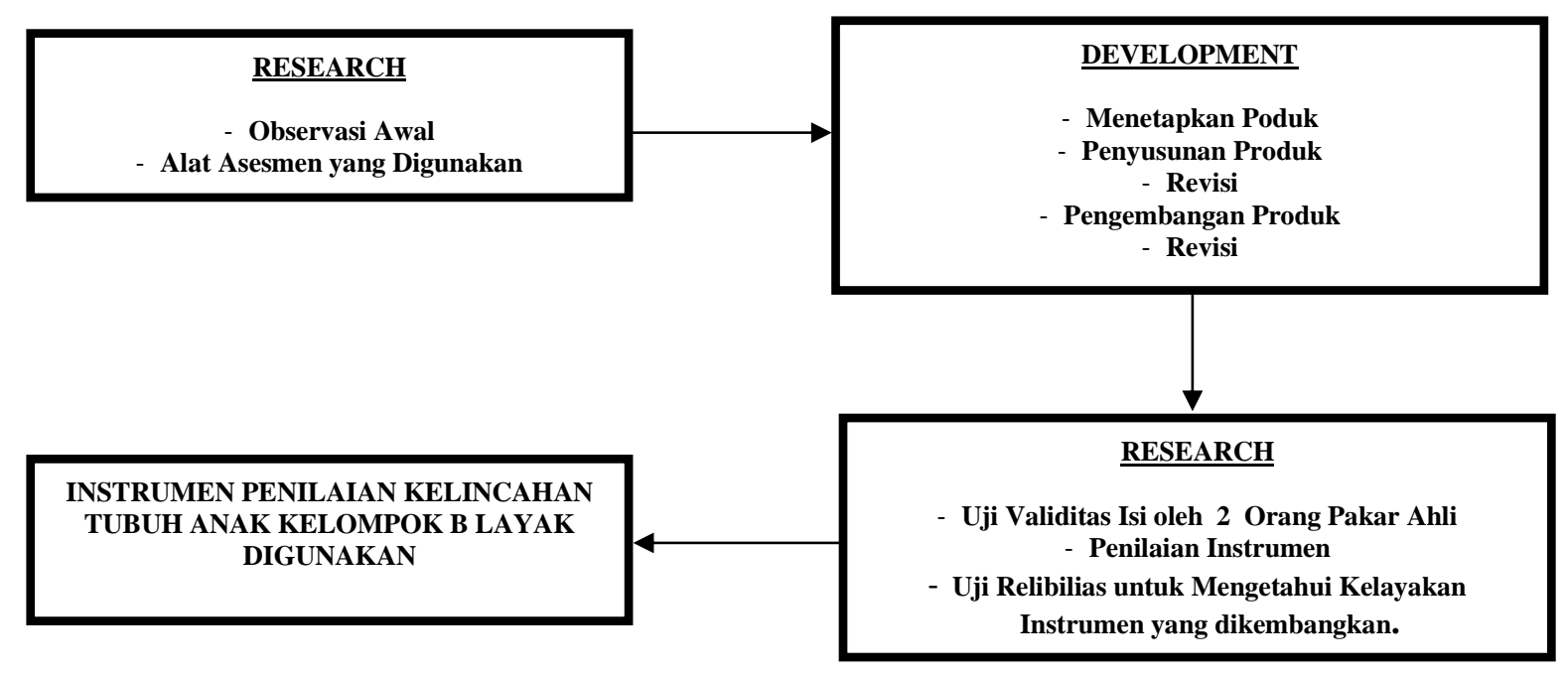

Gambar 1. Bagan Desain Penelitian Pengembangan Model RDR

(Sumber: Nurmasitah, Achmad \& Prasetyaningtyas, 2017; Wanto et al., 2020)

Subjek penelitian merupakan dimana data penelitian ini didapatkan. subjek studi meliputi alat penilaian kelincahan tubuh terhadap anak usia dini yang digunakan berupa kuesioner dengan jumlah pernyataan sebanyak 16 butir. Kuesioner merupakan cara pengumpulan data yang berisi sekumpulan pertanyaan terkait informasi sesuatu yang harus dijawab responden (Purnomo \& Palupi, 2016; Salamah, 2018). Kuesioner yang digunakan dalam penelitian ini berupa pernyataan tertutup untuk memperoleh data terkait kelincahan tubuh pada anak usia dini dengan jumlah anak sebanyak 51 anak. Objek dalam penelitian ini merupakan pakar I dan pakar II yang berjumlah 2 orang. Metode pengumpulan data pada penelitian ini merupakan observasi, wawancara dan kuesioner. Observasi dan wawancara dilakukan untuk mengetahui permasalahan yang ada dilapangan. Dilakukan dengan memberikan lembar relevansi kepada pakar ahli untuk menguji kelayakan instrumen penilaian kelincahan tubuh anak usia dini. Metode pengumpulan data dilakukan untuk memperoleh data yang sesuai dengan data yang dibutuhkan. Instrumen yang digunakan dalam penelitian ini berupa instrumen non tes berupa kuesioner. Adapun kisi-kisi kuesioner dari pakar ahli yaitu kesesuaian kebutuhan teori, aspek perkembangan, manfaat instrumen dan cara penyajian. Penilaian pada setiap butir menggunakan skala likert dengan jawaban, berkembang sangat baik (BSB) diberikan skor 
4, berkembang sesuai harapan (BSH) diberikan skor 3, mulai berkembang (MB) diberikan skor 2, dan belum berkembang (BB) diberikan skor 1 .

Teknik analisis data yang digunakan meliputi analsisi validitas isi dan analisis reliabilitas instrumen. Validitas isi berkaitan dengan ketepatan isi dan format instrumen (Yusup, 2018; Kurniawan \& Puspitaningtyas, 2016b). Validitas isi instrumen penelitian ini diuji oleh dua orang pakar ahli dan skor hasilnya dimasukkan dalam tabel tabulasi silang. Hasil validasi kedua pakar ahli yang sudah dimasukkan ke dalam tabel tabulasi silang dianalisis menggunakan rumus Gregory, kemudia hasil perhitungan tersebut dibandingkan dengan kriteria koefisien validitas isi. Reliabilitas instrumen berkaitan dengan konsistensi hasil pengukuran dari instrumen yang digunakan. (Alam, Japar \& Asnur, 2019c; Kurniawan \& Puspitaningtyas, 2016c) instrumen dengan reliabilitas yang tinggi meskipun digunakan dalam jangka waktu yang berbeda-beda akan menunjukkan hasil yang relativ sama. Untuk mengetahui koefisien reliabilitas instrumen penilaian kelincahan tubuh anak usia dini dihitung menggunakan rumus Cronbach Alpha, kemudian hasil tersebut dibandingkan dengan kriteria reliabilitas instrumen..

\section{HASIL DAN PEMBAHASAN}

\section{Hasil}

Pengembangan instrumen penilaian menggunakan model pengembangan RDR dengan beberapa tahap yaitu: studi lapangan/pendahuluan, pengembangan, dan uji efektifitas produk. Prosedur yang dilakukan dalam penelitian ini sebagai berikut. Tahap utama yaitu, tahap pengujian melakukan analisis keadaan lapangan (research) terkait untuk memperoleh informasi untuk merencanakan instrumen penilaian sesuai dengan masalah yang dialami. Analisis kebutuhan lapangan dilakukan di taman kanakkanak sebelum pembatasan sosial dilakukan. Hasil pertemuan yang dilakukan dengan pendidik menunjukkan bahwa instrumen penilaian untuk mengukur kelincahan tubuh pada anak usia dini belum pernah dibuat oleh pendidik serta keterbatasan media dan metode yang digunakan dalam proses pembelajaran dan penilaian kelincahan tubuh anak. Dengan hasil pengamatan yang dilakukan penulis merancang instrumen penilaian kelincahan tubuh pada anak usia dini dengan berbagai kegiatan dan media yang bervariasi. Tahap selanjutnya, yaitu pengembangan (development) hasil analisis kebutuhan lapangan yang dilakukan sebelumnya dengan menetapkan dan menyusun instrumen. Kegiatan utama pada tahap ini meliputi penyusunan kisi-kisi instrumen dan penyusunan penilaian non tes dalam bentuk kuesioner tertutup untuk diisi oleh pendidik sesuai dengan kemampuan anak. Dalam Menyusun kisi-kisi instrumen didukung dengan beberapa teori perkembangan anak usia dini dan sesuai dengan data lapangan yang didapat. Adapun kisi-kisi instrumen penilaian kelincahan tubuh pada anak disajikan pada Tabel 1.

Tabel 1. Kisi-Kisi Instrumen Penilaian Kelincahan Tubuh Anak Usia Dini

\begin{tabular}{|c|c|c|c|}
\hline Aspek & Dimensi & Indikator & Butir \\
\hline $\begin{array}{l}\text { Kelincahan } \\
\text { Tubuh }\end{array}$ & Kecepatan & $\begin{array}{l}\text { Anak mampu berlari } 10 \text { kali putaran dengan jarak } 10 \text { meter } \\
\text { dalam waktu } 1 \text { menit. }\end{array}$ & $1-2$ \\
\hline \multirow[t]{7}{*}{ Anak } & & $\begin{array}{l}\text { Anak mampu melompati } 5 \text { lingkaran tanpa menginjak garis dalam } \\
\text { waktu } 1 \text { menit. }\end{array}$ & $3-4$ \\
\hline & Kekuatan & $\begin{array}{l}\text { Anak mampu memindahkan } 5 \text { bungkus beras dalam plastik } \\
\text { dengan berat } 1 \text { kg dalam waktu } 1 \text { menit dengan jarak } 7 \text { meter. }\end{array}$ & $5-6$ \\
\hline & & $\begin{array}{l}\text { Anak mampu memindahkan } 5 \text { pot bunga berisi tumbuhan } \\
\text { dengan berat } 1.5 \mathrm{~kg} \text { dalam waktu } 1 \text { menit dengan jarak } 7 \text { meter. }\end{array}$ & 7-8 \\
\hline & $\begin{array}{l}\text { Keseimbanga } \\
\mathrm{n}\end{array}$ & $\begin{array}{l}\text { Anak mampu menahan tubuhnya dengan } 1 \text { kaki selama } \\
1 \text { menit. }\end{array}$ & $9-10$ \\
\hline & & Anak mampu melompat dengan Kaki bergantian tanpa terjatuh. & $11-12$ \\
\hline & $\begin{array}{l}\text { Koordinasi } \\
\text { Gerak }\end{array}$ & $\begin{array}{l}\text { Anak mampu memasukkan } 15 \text { bola kedalam keranjang dalam } \\
\text { waktu } 1 \text { menit. }\end{array}$ & $13-14$ \\
\hline & & $\begin{array}{l}\text { Anak mampu berlari sambil memegang dan emindahkan } \\
\text { bendera dalam waktu } 1 \text { menit. }\end{array}$ & $15-16$ \\
\hline
\end{tabular}

(Sumber: Novitasari, Nasirun \& Delrefi, 2019 ;Farida, 2016)

Tahap penelitian/uji efektifitas produk (research) merupakan tahap terakhir yang dilakukan setelah penyusunan instrumen untuk mengetahui kelincahan tubuh pada anak usia dini. Pelaksanaan pengujian item oleh pakar ahli dilakukan untuk mendapatkan keefektifan produk yang dirancang. Setelah instrumen di susun, maka dilakukan evaluasi terhadap instrumen yang terdiri dari dua jawaban penilaian, yaitu jawaban relevan dan tidak relevan. Kedua pakar ahli dipilih karena berkompeten serta memahami perkembangan anak usia dini dan bagaimana langkah-langkah atau prosedur yang baik digunakan dalam 
melakukan penilaian dengan menggunakan instrumen dalam pembelajaran. Selanjutnya dilakukan perbaikan instrumen sesuai dengan masukan dan arahan yang diberikan oleh kedua pakar ahli. Perbaikan diselesaikan untuk menyempurnakan instrumen. Skor penilaian yang telah disurvei oleh dua pakar ahli kemudian diuraikan untuk mengetahui validitas instrumen penilaian tersebut. Hasil validitas dan reliabilitas yang sangat tinggi tersebut dikarenakan instumen penilaian yang direncanakan bergantung pada hasil penelitian yang dilakukan. Sehingga sesuai dengan target yang ingin dicapai. Dengan melakukan analisis kebutuhan untuk mengevaluasi pembelajaran anak usia dini yang memenuhi syarat untuk memberikan penilaian yang tepat. Hasil evaluasi terhadap dua pakar ahli pada instrumen menunjukkan bahwa dari 16 item pernyataan yang ada, 14 item dinyatakan relevan dan 2 item dinyatakan tidak relevan. Item-item intrumen yang memiliki kemiripan luar biasa antara satu dengan yang lainnya dianggap tidak mewakili kemampuan kelincahan tubuh anak usia dini, sehingga item tersebut tidak valid. Namun demikian meskipun terdapat 2 item yang tidak relevan yang dideteksi oleh pakar II, namun masih terdapat 14 item yang yang relevan dan diakui sehingga instrumen tersebut dianggap sah atau valid dan layak digunakan.

Instrumen penilaian kelincahan tubuh pada anak usia dini terdapat 16 butir pernyataan yang disusun, dengan kriteria penilaian menggunakan skala likert, berkembang sangat baik (BSB) diberikan skor 4, berkembang sesuai harapan (BSH) diberikan skor 3, mulai berkembang (MB) diberikan skor 2, dan belum berkembang (BB) diberikan skor 1. Kemudian instrumen yang dibuat diujikan kepada pakar ahli dengan kriteria penilaian relevan dan tidak relevan. Pada pengujian instrumen pakar I dinyatakan relevan dengan lebih spesifik angka 1,2,3,4,5,6,7,8,9,10,11,12,13,14,15,16, dan pada pengujian instrumen pakar II dari 16 pernyataan yang ada, 16 pernyataan yang dinyatakan relevan dengan lebih spesifik angka $1,2,5,6,7,8,9,10,11,12,13,14,15,16$ dan angka yang tidak relevan adalah angka 3 dan 4 . Kemudian hasil pengujian pakar ahli dianalisis menggunakan rumus Gregory diperoleh hasil sebesar 0,87 dengan kriteria sangat tinggi dan reliabilitas menggunakan rumus Cronbach Alpha diperoleh hasil 0,98 dengan kriteria sangat tinggi. Hasil analisis keabsahan instrumen penilaian kelincahan tubuh pada anak usia dini adalah 0,87 dan berada pada standar yang sangat tinggi. Berdasarkan hasil ini instrumen peniilaian kelincahan tubuh pada anak usia dini cocok untuk digunakan. Validitas instrumen merupakan alasan instrumen yang berkualitas.

\section{Pembahasan}

Hasil pengujian validitas yang sangat tinggi tersebut diyakini bahwa instrumen ini dapat dimanfaatkan dengan baik, khususnya dalam penilaian kelincahan tubuh anak usia dini. Instrumen penilaian kelincahan tubuh pada anak usia dini layak diterapkan dalam proses penilaian pembelajaran disebabkan oleh beberapa faktor sebagai berikut. Pertama, instrumen penilaian kelincahan tubuh pada anak usia dini layak digunakan dalam proses penilaian dalam pembelajaran anak usia dini karen efektif dan akurat. Penilaian ialah suatu aktivitas pencarian informasi berkelanjutan serta merata mengenai alur pembelajaran maupun hasil pembelajaran yang telah diraih peserta didik, merata mengenai penilaian aspek sikap, pengetahuan, kemampuan, dan nilai-nilai (Alam, Japar \& Asnur, 2019; Ariani, Saptaningrum \& Siswanto, 2016). Sesuai dengan tujuan instrumen penilaian ini dibuat agar mampu menghasilkan penilaian yang akurat dan efektif digunakan oleh pendidik sehingga tercapainya tujuan pembelajaran dengan maksimal dan sesuai dengan tingkat kemampuan anak usia dini. Kedua, instrumen penilaian kelincahan tubuh pada anak usia dini layak digunakan dalam proses pembelajaran. Karena dalam kegiatan instrumen kelincahan tubuh ini dilakukan aktivitas pembelajaran dipadukan dengan aktivitas bermain sehingga secara langsung dapat merangsang motorik anak. Temuan penelitian sebelumnya juga menyatakan bahwa aktivitas bermain ialah aktivitas yang sangat disukai oleh anak karena itu anak akan lebih mudah memahami pembelajaran yang diberikan (Rahmatia, Pajarianti, Kadir, Ulpi \& Yusuf, 2021; Setyawati, Permanasari \& Yuniarti 2017; Swastrini, Antara \& Tirtayani, 2016). Kegiatan dalam instrumen ini juga menciptakan suasana belajar yang nyaman dan menyenangkan bagi anak. Suasana yang menyenangkan dalam pembelajaran dapat memudahkan anak menerima informasi dalam pembelajaran (Antara \& Aditya, 2019; Ratna, Natajaya \& Dantes, 2019).

Kelebihan instrumen penilaian kelicahan tubuh pada anak yaitu mengukur kemampuan anak secara langsung dengan tugas-tugas yang terdapat didalam instrumen penilaian (Maulida, Dibia \& Astawan, 2020; Yusup, 2018), pendidik mampu menilai anak dengan keseluruhan tingkat perkembangan kelincahan tubuh anak dengan efektif dan akurat, mampu membuat pembelajaran lebih menyenangkan dan tidak membosankan bagi anak karena menggunakan berbagai macam media dengan bentuk dan ukuran yang berbeda serta memiliki tekstur yang berbeda pula (Afinda, Aisyah \& Wijayanti, 2019; Ahmadi, Rini \& Wiratama, 2015). Proses pembuatan instrumen ini dengan menggunakan teori-teori perkembangan fisik motorik kemudian diuji oleh pakar ahli agar dapat melihat keabsahan instrumen ini dan bisa digunakan oleh guru sebagai alat penilaian. Penelitian relevan lainnya tentang instrumen penilaian kelincahan tubuh anak usia dini menyatakan bahwa model dan instrumen kelincahan tubuh yang diterapkan efektif 
digunakan dan mampu meningkatkan kemampuan anak (Widiastuti \& Ridwan, 2018c; Yulianti \& Fithroni, 2019b). Temuan lainnya tentang instrumen penilaian perkembangan anak yang dilakukan dengan menggunkan model RDR dengan hasil analisis data validitas dan reliabilitas yang sangat tinggi sehingga instrumen layak digunakan dan diterapkan dalam pembelajaran (Lestari, Antara \& Ujianti 2021; Novitasari, Nasirun \& Delrefi, 2019; Ariani, Jampel \& Antara, 2021). Berdasarkan temuan penelitian tersebut, dapat disimpulkan bahwa instrumen penilaian yang dikembangkan dapat memfasilitasi pendidik dalam proses penilaian kelincahan tubuh anak dan dapat memberikan peserta didik motivasi dan hal baru dalam proses pembelajaran yang dilakukan dengan kegiatan dan alat permainan yang beragam sehingga dapat mengembangkan kelincahan tubuh anak dengan baik dan maksimal.

Implikasi penelitian ini yaitu instrumen penilaian yang telah dikembangkan dapat digunakan oleh guru sebagai alat penilaian yang dapat memfasilitasi pendidik dalam proses penilaian dalam pembelajaran. Instrumen ini juga dapat meningkatkan semangat anak dalam proses pembelajaran, sehingga berdampak baik pada peningkatan perkembangan fisik motorik anak khususnya perkembangan kelincahan tubuh pada anak. Keterbatasan atau kelemahan pada studi ini terjadi dikarenakan perlakuan pembatasan sosial yang disebabkan oleh pandemi Covid-19, oleh sebab itu penelitian hanya dilakukan dengan menyajikan instrumen penilaian kelincahan tubuh pada anak usia dini yang layak serta efisien diterapkan pada pembelajaran di sekolah. Terdapat saran yang bisa diterapkan pertama, agar penelitian ini dapat digunakan untuk melihat setiap perkembangan kelincahan tubuh anak, kedua, untuk dipakai sebagai sumber permasalahan saat pembelajaran dan sebagai pedoman dalam menyusun instrumen penilaian melalui pencarian referensi bervariasi.

\section{SIMPULAN}

Instrumen asesmen atau penilaian yang telah dikembangkan mendapatkan kategori valid dari pakar ahli. Dapat disimpulkan bahwa instrumen penilaian kelincahan tubuh pada anak usia dini layak diterapkan dalam proses pembelajaran karena memudahkan pendidik dalam menilai kemampuan kelincahan tubuh pada anak usia dini sehingga kemampuan anak dapat meningkat dengan maksimal.

\section{DAFTAR RUJUKAN}

Afinda, B. N., Sari, R., Aisyah, S., \& Wijayanti, I. E. (2019). Cooperative- STAD dengan word square: Dampaknya terhadap motivasi dan hasil belajar siswa. Jurnal Pendidikan IPA Veteran, 3, 17-27. https://doi.org/https://doi.org/10.31331/jipva.v3i1.773.

Ahmadi, C., Rini, E. S., \& Wiratama, I. W. A. (2015). Media Pembelajaran Pengenalan Rupa dan Karakter Tokoh Wayang Purwa Berbasis Android. Jurnal Eksplora Informatika, 4, 197-208. https://doi.org/https://eksplora.stikom-bali.ac.id/index.php/eksplora/article/view66.

Aji, B., \& Winarno, M. E. (2016). Pengembangan Instrumen Penilaian Pengetahuan Mata Pelajaran Pendidikan Jasmani Olahraga Dan Kesehatan (PJOK) Kelas VIII Semester Gasal. Jurnal Pendidikan, April 2015, 21-22. https://doi.org/http://dx.doi.org/10.17977/jp.v1i7.6594Alam.

Antara, P. A. (2019a). Implementasi Pengembangan Karakter Anak Usia Dini Dengan Pendekatan Holistik. Jurnal Ilmiah VISI PGTK PAUD Dan Dikmas, 14(1), 17-26. https://doi.org/http://doi.org/JIV.1401.8.

Antara, P. A. (2019b). Pengaruh Model Pembelajaran Tari Kreatif Terhadap Kemampuan Motorik Kasar Kelompok B Gugus I Kecamatan Banjar. Jurnal Pendidikan Anak Usia Dini Undiksha, 7(2), 239. https://doi.org/10.23887/paud.v7i2.19010.

Ariani, K., Jampel, I. N., \& Antara, P. A. (2021). Pengembangan Instrumen Penilaian Kemampuan Mengenal Lambang Bilangan Pada Anak Kelompok A. Jurnal Golden Age, 5(02), 119-128. https://doi.org/https://doi.org/10.29408/jga.v5i01.3362.

Cahyaningrum, E. S., Sudaryanti, S., \& Purwanto, N. A. (2017). Pengembangan Nilai-Nilai Karakter Anak Usia Dini Melalui Pembiasaan Dan Keteladanan. Jurnal Pendidikan Anak, 6(2), 203-213. https://doi.org/10.21831/jpa.v6i2.17707.

Darihastining, S., Aini, S. N., Maisaroh, S., \& Mayasari, D. (2021). Penggunaan Media Audio Visual Berbasis Kearifan Budaya Lokal pada Anak Usia Dini. Jurnal Obsesi: Jurnal Pendidikan Anak Usia Dini, 5(2), 1594-1602. https://doi.org/10.31004/obsesi.v5i2.923.

Fadlullah. (2017). Pendidikan Anak Usia Dini dalam Perspektif Islam. Jurnal Pendidikan Islam, 6(2), 308320. https://doi.org/10.29313/tjpi.v6i2.3195.

Farida, A. (2016). Urgensi Perkembangan Motorik Kasar Pada Perkembangan Anak Usia Dini. Raudhah.

Fauziddin, M. (2015). Peningkatan Kemampuan Matematika Anak Usia Dini Melalui Jam Pintar di Taman kanak-Kanak Pembina Kec. bangkinang Kota. Jurnal Obsesi : Jurnal Pendidikan Anak Usia Dini, 1(1), 
49-54. https://doi.org/https://doi.org/https://doi.org/10.31004/obsesi.v1i1.55.

Fitriani, R. (2018). Perkembangan Fisik Motorik Anak Usia Dini. Jurnal Golden Age, 2(01), 25. https://doi.org/10.29408/goldenage.v2i01.742.

Khadijah, Arlina, Hardianti, R. W., \& Maisarah. (2021). Model Pembelajaran Bank Street dan Sentra, serta Pengaruhnya terhadap Sosial Emosional Anak. Jurnal Obsesi : Jurnal Pendidikan Anak Usia Dini, 5(2), 1960-1972. https://doi.org/10.31004/obsesi.v5i2.1054.

Kurniawan, A. W., \& Puspitaningtyas, Z. (2016). Metode Penelitian Kuantitatif. Pandiva Buku.

Lestari, M. E., Antara, P. A., \& Ujianti, P. R. (2021). Development of Kindergarten Child Stability Instruments. Indonesian Journal of Educational Research and Review, 4(1), 9. https://doi.org/10.23887/ijerr.v4i1.30636.

Melendez, C. M., \& Tafur, A. A. (2021). Parental Competencies in Mothers of Infants with Disabilities and their Relationship to Adaptive Behavior and Motor Development. International Journal of Early Childhood Special Education, May. https://doi.org/10.9756/INT-JECSE/V13I1.211015.

Maulida, I., Dibia, I. K., \& Astawan, I. G. (2020). The Development of Social Attitude Assessment Instrument and Social Studies Learning Outcomes Grade IV on Theme of Indahnya Keragaman di Negeriku. Indonesian Journal of Education and Riview, 3(2), 12-18. https://doi.org/http://dx.doi.org/10.23887/ijerr.v3i2.25823.

Novitasari, Reni. Nasirun, M. D. (2019). Meningkatkan Kemampuan Motorik Kasar Anak Melalui Bermain Dengan Media Hulahoop Pada Anak Kelompok B PAUD AL-Syafaqoh Kabupaten Rejang Lebong. Jurnal Ilmiah Potensia, 4(1), 6-12. https://doi.org/10.33369/jip.4.1.6-12.

Purnomo, P., \& Palupi, M. S. (2016). Pengembangan Tes Hasil Belajar Matematika Materi Menyelesaikan Masalah yang Berkaitan dengan Waktu, Jarak dan Kecepatan untuk Siswa Kelas V. Jurnal Penelitian (Edisi Khusus $\quad 20 . \quad$ hGSD), 2 https://doi.org/https://ejournal.usd.ac.id/index.php/JP/article/view/872.

Putri, D. K., Handayani, M., \& Akbar, Z. (2020). Pengaruh Media Pembelajaran dan Motivasi Diri terhadap Keterlibatan Orang Tua dalam Pendidikan Anak. Jurnal Obsesi : Jurnal Pendidikan Anak Usia Dini, 4(2), 649. https://doi.org/10.31004/obsesi.v4i2.418.

Rahmatia, R., Pajarianto, H., Kadir, A., Ulpi, W., \& Yusuf, M. (2021). Pengembangan Model Bermain Konstruktif dengan Media Balok untuk Meningkatkan Visual-Spasial Anak. Jurnal Obsesi : Jurnal Pendidikan Anak Usia Dini, 6(1). https://doi.org/10.31004/obsesi.v6i1.1185.

Ramadhani, C., \& Zulminiati. (2021). Efektivitas Permainan Big Maze Terhadap Kemampuan Mengenal Angka Usia 5-6 Tahun Di Taman Kanak-Kanak An-Nur. Jurnal Pertumbuhan Dan Pekembangan Anak Usia Dini, 18(229), 90-95. https://doi.org/10.17509/edukids.v18i2.33955.

Ratna, A., Natajaya, I. N., \& Dantes, K. R. (2019). Determinasi Servant Leadership , Karakteristik Individu , Motivasi Kerja, Dan Kepuasan Kerja Terhadap Komitmen Guru Di Sman 1 Gianyar. Jurnal $\begin{array}{lll}\text { Dministrasi Pendidikan 10(2), } & \text { 119-124. }\end{array}$ https://doi.org/https://doi.org/10.23887/japi.v10i2.2798.

Ruqoyyah, F., \& Meidita, L. I. (2021). Permainan Karpet Engkle: Aktivitas Motorik untuk Meningkatkan Keseimbangan Tubuh Anak Usia Dini. 5(2), 1187-1198. https://doi.org/10.31004/obsesi.v5i2.754.

S., Japar, M., \& Asnur, M. N. A. (2019). Pengembangan Instrumen Tes Siswa Tingkat Sekolah Dasar di Kabupaten Kuningan. Jurnal Ilmu Kependidikan, 8(1), 59. https://doi.org/10.33506/jq.v8i1.389.

Salamah, U. (2018). Penjaminan Mutu Penilaian Pendidikan. Jurnal Evaluasi, 2(October). https://doi.org/10.32478/evaluasi.v2i1.79.

Setyawati, Permanasari, \& Yuniarti. (2017). Meningkatkan Kecerdasan Musikal Melalui Bermain Alat Musik Angklung (Penelitian Tindakan Pada Anak Kelompok B Usia 5-6 Tahun Di TK Negeri Pembina Kota Serang-Banten). JPKS (Jurnal Pendidikan Dan Kajian Seni), 2(1). http://dx.doi.org/10.30870/jpks.v2i1.2503.

Sukoyo, J., Kurniati, E., \& Utami, E. S. (2021). Engklek Game and Its Benefits for Early Children's Development. International Journal of Early Childhood Special Education, 13(1), 20-27. https://doi.org/10.9756/INT-JECSE/V13I1.211003.

Swastrini, Antara, P. A., \& Tirtayani, L. A. (2016). Penerapan Bermain Ular Tangga Untuk Meningkatkan Kemampuan Kerjasama Kelompok B1 di TK Widya Sesana Sangsit. Pendidikan Anak Usia Dini, 4(2). https://doi.org/http://dx.doi.org/10.23887/paud.v4i2.7764.

Trisnaningsih, S. I., Wiyasa, I. K. N., \& Darsana, I. W. (2019). Pengaruh Lari Zig-Zag Berbantuan Kursi Terhadap Perkembangan Motorik Kasar Anak Kelompok B Tk Sila Dharma Tahun Ajaran 2018/2019. Jurnal Pendidikan Anak Usia Dini Undiksha, 7(1), 100-109. https://doi.org/10.23887/paud.v7i1.18764.

Umami, R., Rusdi, M., \& Kamid, K. (2021). Pengembangan Instrumen Tes untuk Mengukur Higher Order Thinking Skills (HOTS) Berorientasi Programme for International Student Ssessment (PISA) pada 
Peserta Didik. JP3M (Jurnal Penelitian Pendidikan Dan Pengajaran Matematika), 7(1), 57-68. https://doi.org/10.37058/jp3m.v7i1.2069.

Usher, W. (2019). Agility As a Predictor Of Physical Literacy , Activity Levels and Sport Involvement. Cogent Education, 6(1). https://doi.org/10.1080/2331186X.2019.1661582.

Uzun, A., \& Akbulut, A. (2020). International Journal of Applied Exercise Physiology. International Journal of Applied Exercise

Physiology,

August. https://doi.org/https://www.researchgate.net/publication/343762230.

Wanto, S., Okilanda, A., Arismana, Lanos, M. E. C., Putra, D. D., Lestari, H., Awali, M., \& Oktariyana. (2020). Kupas Tuntas Penelitian Pengembangan Model. Jurnal PkM Ilmu Kependidikan, 3(2). https://doi.org/http://dx.doi.org/10.31851/dedikasi.v3i1.3023.

Wulandari, H., \& Purwanta, E. (2020). Pencapaian Perkembangan Anak Usia Dini di Taman Kanak-kanak selama Pembelajaran Daring di Masa Pandemi Covid-19. Jurnal Obsesi : Jurnal Pendidikan Anak Usia Dini, 5(1), 452. https://doi.org/10.31004/obsesi.v5i1.626.

Zahro, I. F. (2015). Penilaian dalam Pembelajaran Anak Usia Dini. Jurnal Program Studi Pendidikan Guru PAUD STKIP Siliwangi $\quad$ Bandung, 111. https://doi.org/https://doi.org/10.22460/ts.v1i1p92-111.95.

Zeptyani, P. A. D., \& Wiarta, I. W. (2020). Pengaruh Project-Based Outdoor Learning Activity Menggunakan Media Audio Visual Terhadap Perilaku Belajar Anak Usia Dini. Jurnal Pendidikan Anak Usia Dini Undiksha, 8(June), 69-79.

Zuliani, D., Florentinus, T. S., \& Ridlo, S. (2017). Pengembangan Instrumen Penilaian Karakter pada Siswa Kelas IV Sekolah Dasar. Journal of Research and Educational Research Evaluation, 6(1), 46-54. https://doi.org/10.15294/jrer.v6i1.16207. 